\title{
Animals and their products utilized as medicines by the inhabitants surrounding the Ranthambhore National Park, India Madan Mohan Mahawar*1 and DP Jaroli ${ }^{2}$
}

\author{
Address: ${ }^{1}$ Department of Zoology, Government Post Graduate College, Sawai Madhopur, Rajasthan, India and ${ }^{2}$ Department of Zoology, \\ University of Rajasthan, Jaipur, Rajasthan, India \\ Email: Madan Mohan Mahawar* - madanmohanmahawar@yahoo.co.in; DP Jaroli - jaroli28@uniraj.ernet.in \\ * Corresponding author
}

Published: 03 November 2006

Journal of Ethnobiology and Ethnomedicine 2006, 2:46 doi:10.1 186/1746-4269-2-46

This article is available from: http://www.ethnobiomed.com/content/2/1/46

(C) 2006 Mahawar and Jaroli; licensee BioMed Central Ltd.

This is an Open Access article distributed under the terms of the Creative Commons Attribution License (http://creativecommons.org/licenses/by/2.0), which permits unrestricted use, distribution, and reproduction in any medium, provided the original work is properly cited.
Received: 28 July 2006

Accepted: 03 November 2006

\begin{abstract}
The present ethnozoological study describes the traditional knowledge related to the use of different animals and animal-derived products as medicines by the inhabitants of villages surrounding the Ranthambhore National Park of India (Bawaria, Mogya, Meena), which is well known for its very rich biodiversity. The field survey was conducted from May to July 2005 by performing interviews through structured questionnaires with 24 informants (16 men and 8 women), who provided information regarding therapeutic uses of animals. A total of 15 animals and animal products were recorded and they are used for different ethnomedical purposes, including tuberculosis, asthma, paralysis, jaundice, earache, constipation, weakness, snake poisoning. The zootherapeutic knowledge was mostly based on domestic animals, but some protected species like the collared dove (Streptopelia sp.), hard shelled turtle (Kachuga tentoria), sambhar (Cervus unicolor) were also mentioned as important medicinal resources. We would suggest that this kind of neglected traditional knowledge should be included into the strategies of conservation and management of faunistic resources in the investigated area.
\end{abstract}

\section{Background}

The healing of human ailments by using therapeutics based on medicines obtained from animals or ultimately derived from them is known as zootherapy [1]. As Marques states, "all human culture which presents a structured medical system will utilize animals as medicines" [2]. The use of animals for medicinal purposes is part of a body of traditional knowledge which is increasingly becoming more relevant to discussions on conservation biology, public health policies, sustainable management of natural resources, biological prospection, and patents [3]. Research interest and activities in the areas of ethnobiology and ethnomedicine have increased tremendously in the last decade. Since the inception of the disciplines, scientific research in ethnobiology and ethnomedicine has made important contributions to understanding traditional subsistence and medical knowledge and practice [4]. But in India the traditional knowledge system is fast eroding due to urbanization. So there is an urgent need to inventorise and record all ethnobiological information among the different ethnic communities before the traditional cultures are completely lost [5]. A lot of work has been done in the Ranthambhore National Park on the medicinal plants \& plant products and documented too, but there is a definite scarcity of such knowledge when it comes to animal products. Thus there is an urgent need to make such study in the field of zootherapy and document it, so that it can be put to the welfare of human kind. Therefore keeping this aspect in view, we have undertaken this study. 


\section{Study area}

The Ranthambhore National Park (250 54' N - $26012^{\prime} \mathrm{N}$ and $76022^{\prime} \mathrm{E}-76039^{\prime} \mathrm{E}$ ) at the junction of the Aravalis and the Vindhyas (mountain ranges) is a unique juxtaposition of natural richness, standing out conspicuously in the vast, arid and denuded tract of eastern Rajasthan, barely 14 kilometer from the town, Sawai Madhopur. Being a typical representative of dry-deciduous dhok (Anogeissus pendula) forest, the vegetation of Ranthambhore is considered as i) Tropical Dry Deciduous Forest and ii) Tropical Thorn Forest [6]. The climate is dry-subtropical with four distinct seasons: summer (March to June), followed by monsoon (July-August), post-monsoon (SeptemberOctober) and winter (November-February). Average annual rainfall of about $800 \mathrm{~mm}$ is received mostly during July-September. From socio-cultural point of view, the region exhibits a great ethnic and cultural diversity. The present study was mainly conducted in the villages surrounding Ranthambhore national park, Rajasthan (figure 1). Most of the information was collected from Mogya and Bawaria people, which are living around the national park.

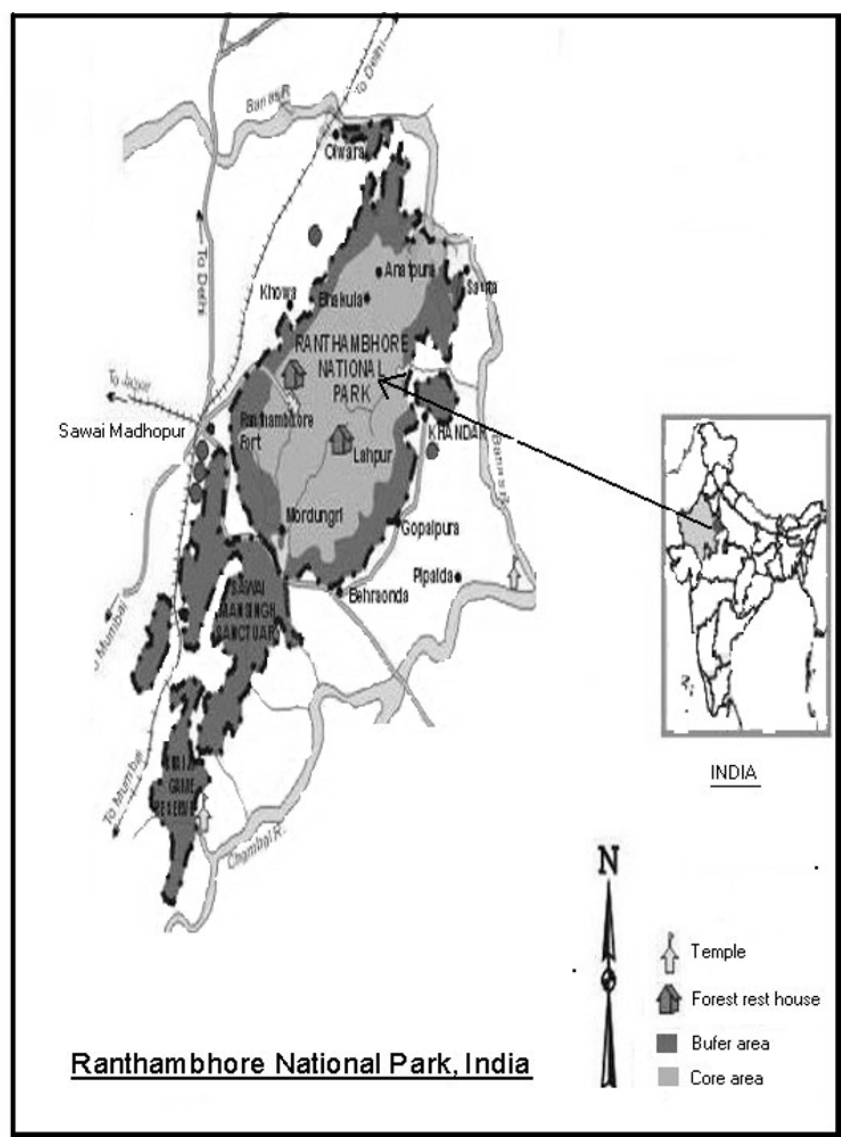

Figure I

Map of the study areaxsxs.

\section{Methodology}

Data were obtained through field survey conducted from May to July 2005 by performing interview through structured questionnaire with 24 selected people (Informants), to collect information about traditional knowledge regarding use of animals and their products. These informants were local herbalists, healers, farmers, and midwives. The Informants are between 40-74 age groups. The selection of Informants was based on their recognition as experts and knowledgeable members concerning folk medicine. We ask the informants whether they use animals in the healing practices. Then we ask that which animal remedies have been prescribes for which ailment. We also ask the modes of preparation of remedies and how the medicines are administered, since this kind of information indicates how a given medicine can be therapeutically efficient in terms of the right ingredients, the proper dose, and the right length of preparation. According to them, their knowledge of folk medicine was acquired mainly through parental heritage, or because they have experience about medicinal value of animals to heal their kin or themselves. The interviews were recorded and documented. All the animal species were identified by using relevant and standard literature.

\section{Result and discussion}

The present study describes the traditional knowledge of treating various kinds of disease using different animals and their product by inhabitants (Bawaria, Mogya, Meena etc) of villages surrounding the Ranthambhore National Park of India. The information of all local names of the animal, part or product used to cure and methods of preparation were provided by the Informants. In this study, we enlisted 15 animal species, which are being used for 20 medicinal purposes. These animals are used as whole or body part or byproduct like milk, blood, organ, skeleton etc. for the treatment of different kind of ailments including tuberculosis, asthma, paralysis, jaundice, earache, constipation, weakness, snake poison etc. (see table 1).

Since ancient times animals, their parts, and their products have constituted part of the inventory of medicinal substances used in various cultures. This phenomenon is marked by both a broad geographical distribution and very deep historical origins [7]. In Pakistan, 31 substances were listed (animal parts and products), constituting 9\% of all the medicinal substances in the inventory of traditional medicines [8]. Costa-Neto describes the use of 180 animal species as medicinal resources in the state of Bahia, Northeastern Brazil [9]. A survey of traditional materia medica in use in the markets of Israel recorded 20 substances of animal origin [25]. In the states of Maranhão and Paraíba (Northeast Brazil) a survey carried out and recorded 100 animal species was used as medicine [26]. Examination and research show that these sub- 
Table I: List of animals and their parts use for therapeutic purpose in the studied area.

\begin{tabular}{|c|c|c|c|c|c|c|}
\hline English Name & Scientific Name & Local Name & Part used & $\begin{array}{l}\text { No. of Informants } \\
\text { reporting the use }\end{array}$ & $\begin{array}{l}\text { Method of preparation and } \\
\text { medicinal use }\end{array}$ & $\begin{array}{l}\text { Related earlier reported use in } \\
\text { India [Ref.] }\end{array}$ \\
\hline I. Indian ass & Equs hemionus & Gadha & Dung & 2 & $\begin{array}{l}\text { Dung kept in water and after one } \\
\text { day filtered water is given to cure } \\
\text { jaundice. }\end{array}$ & \\
\hline \multirow[t]{4}{*}{ 2. Cow } & Bos indicus & Gai & Urine & 18 & $\begin{array}{l}\text { Weakness due to fever is cure by } \\
\text { drinking urine. }\end{array}$ & \\
\hline & & & Urine & 2 & Given to cure cancer. & \\
\hline & & & Dung + Milk & 20 & $\begin{array}{l}\text { Muscle pain can relieve by smear of } \\
\text { dung and milk mixture. }\end{array}$ & $\begin{array}{l}\text { The Dried dung is burnt and ash is } \\
\text { applied to treat utricaria in } \\
\text { Kachchh [15]. }\end{array}$ \\
\hline & & & Ghee & 5 & $\begin{array}{l}250 \mathrm{gm} \text { Ghee }+100 \mathrm{gm} \text { Black } \\
\text { pepper mixture given orally to } \\
\text { neutralize snake poison. }\end{array}$ & \\
\hline 3. Dog & Canis familiaris & Kukaro & Urine & 22 & Used as eardrop for curing earache. & $\begin{array}{l}\text { Also reported by Naga tribe of } \\
\text { Nagaland [II]. }\end{array}$ \\
\hline \multirow[t]{2}{*}{ 4. Goat } & Capra indicus & Bakri & Urine & 3 & $\begin{array}{l}\text { Urine of goat administered orally } \\
\text { to cure tuberculosis. }\end{array}$ & $\begin{array}{l}\text { Reported by Ao [I2] and Naga [II] } \\
\text { tribe for asthma, T.B., paralysis, and } \\
\text { by Tamilnadu tribe for insect bite } \\
\text { [13]. }\end{array}$ \\
\hline & & & Milk & 22 & $\begin{array}{l}\text { Mouth ulcer is treated by direct } \\
\text { spray of milk from breast of goat to } \\
\text { tongue of a patient. }\end{array}$ & \\
\hline 5. Human & Homo sapiens & Manakh & Urine & 24 & $\begin{array}{l}\text { Human urine is used as antiseptic } \\
\text { for wound healing. }\end{array}$ & $\begin{array}{l}\text { Also reported by Naga tribe of } \\
\text { Nagaland [II]. }\end{array}$ \\
\hline 6. Indian Peafowl & Pavo cristatus & Mor & Leg & 5 & $\begin{array}{l}\text { Peacock's leg is rubbed with water } \\
\text { and this essenced water is used in } \\
\text { ear infections }\end{array}$ & $\begin{array}{l}\text { Also reported by Naga tribe of } \\
\text { Nagaland [II], Bhil of Rajasthan } \\
\text { [19]. Legs boil with oil in kachchh } \\
\text { [15] and Maharastra [17] for similar } \\
\text { purpose. }\end{array}$ \\
\hline 7. Pig & Sus scrofa & Soor & Fat & 12 & $\begin{array}{l}\text { Fat of pig is use as massage cream } \\
\text { in muscular pain. }\end{array}$ & $\begin{array}{l}\text { Also reported by Ao tribe of } \\
\text { Nagaland [12], but fat of pig used } \\
\text { for Hemorrhoids in Tamilnadu } \\
\text { [13]. }\end{array}$ \\
\hline 8. Sambhar & Cervus unicolor & Sambhar & Antler & 2 & $\begin{array}{l}\text { Antler is rubbed with water this } \\
\text { paste is applied in eye ailments. }\end{array}$ & $\begin{array}{l}\text { Also reported in Kachchh of Gujrat } \\
\text { [15]. }\end{array}$ \\
\hline 9. Sheep & Capra sp. & Menda & Milk & 23 & $\begin{array}{l}\text { Used as massage cream in muscular } \\
\text { pain. }\end{array}$ & \\
\hline 10. House sparrow & Passer domesticus & Cheedi & Fecal & 20 & $\begin{array}{l}\text { Fecal matter is applied in the anus } \\
\text { of baby to treat constipation. }\end{array}$ & $\begin{array}{l}\text { Ash of excreta is used for } \\
\text { treatment of asthma in children is } \\
\text { reported in Kchchh [15]. }\end{array}$ \\
\hline II. Pigeon & Columba livia & Kabutar & Fresh blood & 14 & $\begin{array}{l}\text { The fresh blood is massaged } \\
\text { externally to treat paralysis. }\end{array}$ & $\begin{array}{l}\text { Same use reported in Kachchh [15] } \\
\text { and Tamilnadu [13]. }\end{array}$ \\
\hline 12. Collared dove & Streptopelia sp. & Kamedii & Flesh & 3 & $\begin{array}{l}\text { To attain early puberty girls eat } \\
\text { flesh of collared dove. }\end{array}$ & \\
\hline 13. Hardshelled Turtle. & Kachuga tentoria & Kachhua & Carapace & 7 & $\begin{array}{l}\text { Ash of carapace is used in lung } \\
\text { diseases as cough, asthma, T. B. etc. }\end{array}$ & $\begin{array}{l}\text { Ash of Lissemys punctatus' Carapace } \\
\text { is used for healing of internal } \\
\text { injuries, pruritis and cough } \\
\text { (Kachchh) [15]. }\end{array}$ \\
\hline 14. Honey bee & Apis indica & Mokh & Honey & 21 & $\begin{array}{l}\text { Used as eye drops to cure eye } \\
\text { disease. }\end{array}$ & $\begin{array}{l}\text { Honey is used for cough and could. } \\
\text { (Tamilnadu tribes) [13] [16]. }\end{array}$ \\
\hline 15. Bivalves & Mactra sp. & Seepi & Shell & 3 & $\begin{array}{l}\text { Shell of sepia is rubbed with } \\
\text { clarified butter (ghee) and red lead } \\
\text { (sindoor) to apply on acne to cure. }\end{array}$ & \\
\hline
\end{tabular}

stances are similar to those used as remedies throughout human history, irrespective of geographical borders [7].

In India, nearly 15-20 percent of the Ayurvedic medicine is based on animal-derived substances. There are references to nearly 380 types of animal substances in Charaka Samhita [10]. The Hindu religion has used five products (milk, urine, dung, curd and ghee) of the cow for purification since ancient times [27]. Besides immense knowledge has come down to modern times through folklore as various practices became a part of tradition amongst various groups in India (see table 2). Different animals used by the Naga tribe of Nagaland [11], Ao tribe of Nagaland[12], Irular, Kurimba of Tamilnadu[13], Chakhesang tribe of Nagaland[14], Kachch (Gujrat)[15], Kanikar, Pal- iyar of Taminadu[16], Bhil, Gamit, Kokna etc of Maharastra[17], Assam[18], Bhil of Rajasthan[19], Dibrugarh (Assam) [20]etc. has some or the other relevance with the animals that are found to be use by the Mogya, Bawaria, Meena etc. residing in this part of India.

The use of urine drop of Canis familiaris against earache has been also reported amongst the Naga tribe of Nagaland [11]. The urine of Capra indicus has been also reported by Ao and Naga tribes for asthma, T.B., paralysis, $[11,12]$ but the milk of this animal is use for mouth ulcer has never been reported earlier. Pavo cristatus' legs uses for ear infection are also similar in Naga tribe of Nagaland and Bhil of Rajasthan, $[11,19]$ but Legs are boil with oil in kachchh and Maharastra for similar purpose $[15,17]$. Ao 
Table 2: Ethnomedicinal uses of animals reported from different parts of India.

\begin{tabular}{|c|c|c|c|}
\hline Tribes/Ethnic Groups/Region/Indigenous people & Number of animals Reported & Authors & Ref. No. \\
\hline Assam & 5 & Dutta A (1996) & {$[18]$} \\
\hline Sporadic study in India & 20 & Gosh A K, Maiti P K (1996) & [24] \\
\hline Chakhesang of Nagaland & 23 & Kakati and Doulo (2000) & [14] \\
\hline Bhil of Rajasthan & 17 & Sharma S K (2002) & [19] \\
\hline Bhil, Gamit, Kokna etc of Maharastra & 15 & Patil S H (2003) & [17] \\
\hline Chhattisgarh & 10 & Oudhia P (2003) & [23] \\
\hline Chhattisgarh & 7 & Oudhia P (2003) & {$[2 I]$} \\
\hline Bhopalpatnam (chhattisgarh) & 3 & Oudhia P (2003) & [22] \\
\hline Kachch (Gujrat) & 34 & Gupta Leena et al (2003) & {$[15]$} \\
\hline Irular, Kurimba of Tamilnadu & 26 & Solvan A et al (2004) & [13] \\
\hline Kanikar, Paliyar of Taminadu & 11 & Ranjit Singh ASA (2004) & [16] \\
\hline Naga tribe of Nagaland & 26 & Jamir N S et al (2005) & {$[11]$} \\
\hline Dibrugarh (Assam) & 4 & Dilip Kalita (2005) & [20] \\
\hline Ao tribe of Nagaland & 25 & Kakati L N et al (2006) & 12] \\
\hline Mogya, Meena, Bawaria of Rajasthan & 15 & Mahawar, Jaroli (Present study) & \\
\hline
\end{tabular}

tribe of Nagaland [12] also reports the fat of Sus scrofa in muscular pain, but in Tamilnadu this is used for Hemorrhoids [13]. The use of antler of cervus unicolor for eye ailments and the fresh blood of columba livia for paralysis has been also reported in the Kachchh region of Gujarat [15]. The use of fecal matter of Passer domesticus to treat baby constipation, but ash of excreta is used for treatment of asthma in children is reported in Kachchh[15]. The flesh of Streptopelia sp. to attain early puberty and dung of Equs hemionus to cure jaundice has never been reported earlier in India. Ash of Kachuga tentoria' carapace is used in lung diseases as cough, asthma, T. B. etc. but Lissemys punctatus' Carapace is used for healing of internal injuries, prurities and cough in Kachchh region [15].

Noteworthy is the observation that mostly animal byproducts are used in traditional health care systems without any loss to animal. The therapeutic information's is mostly based on domestic animals, but some protected

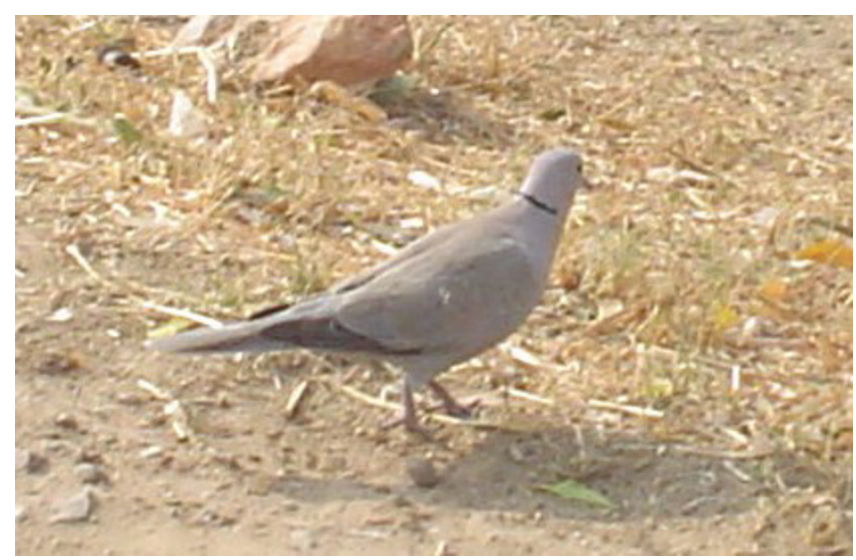

Figure 2

Collared dove. species like the collared dove (Streptopelia $s p$ ) (figure 2), hard shelled turtle (Kachuga tentoria), sambhar (Cervus unicolor) are also included as important medicinal resources in this studied area. Kakati and Doulo enlisted six species as rare among twenty three species among Chakhesang tribe of Nagaland[14]. Inadequate knowledge and myths associated with the therapeutics like children are made to wear beer's claw around their neck as it is suppose to protect them from evil forces, similarly animals like sheep and goat are sacrifice to cause healing as this act is believe to please local gods. However such acts have cause harm to animal life. Thus there is a need to shift the focus from how to obtain the greatest amount of zootherapeutical resources to how to ensure future uses. There is also a need for a transdisciplinary approach to integrate the various aspects of zootherapy in such a way that frameworks or methods to amalgamate ecological and social components of that practice can be increasingly tested [3]. So the traditional knowledge should be included into the strategies of conservation and management of faunistic resources [26]. Further studies are required not only to confirm the presence of bioactive compounds in these traditional remedies, but also to emphasize more sustainable use of these resources.

\section{References}

I. Eraldo M, Costa-Neto : Animal based medicines biological prospection and the sustainable use of zootherapeutic resources. An Acad Bras Cienc 2005, 77(133-43 [http://www.sci elo.br/pdf/aabc/v77n I/a04v77n I.pdf].

2. Marques JGW: A Fauna medicinal dos indios Kuna de Sen Blas (Panama) e a hipotese da universalidade zooterapica. In Paper presented at the 46th Annual Meeting of the Brazilian Society for the Progress of Science Vitória (Brazil): Espírito Santo Federal University; 1994.

3. Alves RR, Rosa IL: Why study the use of animal products in traditional medicines? J Ethnobiol Ethnomedicine 2005, I:5.

4. Andrea Pieroni, Lisa Price Leimar, Ina Vandebroek: Welcome to Journal of Ethnobiology and Ethnomedicine. Journal of Ethnobiology and Ethnomedicine 2005, I:I.

5. Trivedi PC: Ethnobotany: An overview. In Ethnobotany Edited by: Trivedi PC. Jaipur: Aavishkar publisher; 2002:I. 
6. Champion HG, Seth SK: The Forest Types of India New Delhi: The Manager of Publications; 1968.

7. Lev Efraim: Healing with animals in the Levant from the $10^{\text {th }}$ to the $18^{\text {th }}$ century. Journal of Ethnobiology and Ethnomedicine 2006, 2:II

8. Ali SAM, Mahdihassan S: Bazaar medicines of Karachi: The drugs of animal origin. In Bazaar Drugs and Folk Medicine in Pakistan Edited by: Mahdihassan S. Karachi: Hamdard; 1984:69-73.

9. Costa-Neto EM: Implications and applications of folk zootherapy in the state of Bahia, Northeastern Brazil. Sustainable Development I2(3): 16I-I74. 30 Jun 2004

10. Unnikrisnhan PM: Animals in Ayurveda. Amruth 1998:I-15.

II. Jamir NS, Lal P: Ethnozoological practices among Naga tribes. Indian Journal of Traditional Knowledge 2005, 4(I 100-104 [http:// www.niscair.res.in/ScienceCommunication/Research/ournals/rejour/ ijtk/ijtk2k5/ijtk jan05.asp\#a 100].

12. Kakati LN, Bendang Ao, Doulo V: Indigenous Knowledge of Zootherapeutic Use of Vertebrate Origin by the Ao Tribe of Nagaland. J Hum Ecol 2006, 19(3 I63-167 [http:// 72.14.235. I0search?q=cache: vWnHvnWoVAJ:www.krepublishers.com/02-Jour nals//HE//HE-19-0-000-000-2006].

13. Solovan A, Paulmurugan R, Wilsanand V, Ranjith Sing AJA: Traditional therapeutic uses of animals among tribal population of Tamil Nadu. Indian Journal of Traditional Knowledge 2004, 3(2206-207 [http://www.niscair.res.in/ScienceCommunication/ Research/ournals/rejour/ijtk/ijtk2k4/ijtk apr04.asp\#p9].

14. Kakati LN, Doulo V: Indigenous knowledge system of zootherapeutic use by Chakhesang tribe of Nagaland, India. J Hum Ecol 2002, I3(6):419-423.

15. Gupta Leena, Silori CS, Mistry Nisha, Dixit AM: Use of Animals and Animal products in traditional health care systems in District Kachchh, Gujarat. Indian Journal of Traditional Knowledge 2003, 2(1346-356 [http://www.niscair.res.in/ScienceCommunication/ Research/ournals/rejour/ijtk/ijtk2k3/iitk oct03.asp\#p4]

16. Ranjit Singh AJA, Padmalatha C: Ethno-entomologicalpractices in Tirunelveli district, Tamil Nadu. Indian Journal of Traditional Knowledge 2004, 3(4442-446 [http://www.niscair.res.in/ScienceCom munication/Research/ournals/rejour/ijtk/ijtk2k4/ijtk oct04.asp\#p/2].

17. Patil SH: Ethno-medico-zoological studies on Nandurbar district of Maharashtra. Indian Journal of Traditional Knowledge 2003, 2(3297-299 [http://www.niscair.res.in/ScienceCommunication/ Research/ournals/rejour/ijtk/ijtk2k3/iitk jul03.asp\#a I 2].

18. Dilip Kalita, Manashi Dutta, Nazim Islam Forid: Few plants and animal based folk medicines from Dibrugarh District, Assam. Indian Journal of Traditional Knowledge 2005, 4(I):8I-85.

19. Sharma SK: A Study on Ethnozoology of Southern Rajasthan in Ethnobotany. In Ethnobotany Edited by: Trivedi PC. Jaipur: Aavishkar Publisher; 2002:239-253.

20. Dilip Kalita, Manashi Dutta, Nazim Islam Forid: Few plants and animal based folk medicines from Dibrugarh District, Assam. Indian Journal of Traditional Knowledge 2005, 4(I8I-85 [http://www.nis cair.res.in/ScienceCommunication/Research/ournals/rejour/ijtk/ ijtk2k5/ijtk jan05.asp\#a8I].

21. Oudhia P: Traditional knowledge about medicinal insects, mites and spiders in Chhattisgarh, India. Insect Environment $1995 \quad$ [http://www.botanical.com/site/column poudhia/ 06 medicinal insects.html].

22. Oudhia P: Interactions with the traditional healers and natives of Bhopalpatnam region, Chhattisgarh, India having rich traditional medicinal knowledge about common herbs insects and other animals. Research note at Botanical.com 2003 [http:// www.botanical.com/site/column poudhia/I2l bhopalpatnam.html].

23. Oudhia P: Traditional Medicinal knowledge about excreta of different animals used to treat many common diseases in Chhattisgarh, India. Research note at Botanical.com 2003 [http:// www.botanical.com/site/column poudhia/40 animal excreta.html]

24. Ghosh AK, Maiti PK: Investigation of Some Animal drugs (Mammals) used by the Tribal People in India. In Ethnobiology in Human Welfare Edited by: Jain SK. New Delhi: Deep Publications; 1996:200-202.

25. Lev Efraim, Amar Z: Ethnopharmacological survey of traditional drugs sold in Israel at the end of the $20^{\text {th }}$ century. Journal of Ethnopharmacology 2000, 72: 191-205.

26. Rômulo Alves RN, lerecê Rosa L: cnidarians to mammals: The use of animals as remedies in fishing communities in NE Brazil. Journal of Ethnopharmacology 2006.
27. Simoons F): The purification rule of the five products of the cow in Hinduism. Ecology of Food and Nutrition 1974, 3:2 I-34.
Publish with Bio Med Central and every scientist can read your work free of charge

"BioMed Central will be the most significant development for disseminating the results of biomedical research in our lifetime. "

Sir Paul Nurse, Cancer Research UK

Your research papers will be:

- available free of charge to the entire biomedical community

- peer reviewed and published immediately upon acceptance

- cited in PubMed and archived on PubMed Central

- yours - you keep the copyright
Biomedcentral 